\title{
Czy stereotaktyczna radioterapia stanowi równorzędną alternatywę dla chirurgii w I stopniu niedrobnokomórkowego raka płuca? Głos na NIE
}

\author{
Witold Rzyman
}

\author{
Stereotactic radiotherapy should not be an alternative approach \\ to surgery in stage I non-small cell lung cancer
}

\section{Zakres resekcji miąższu płuca \\ w I stopniu zaawansowania klinicznego niedrobnokomórkowego raka płuca (NDRP)}

Lobektomia jest operacją z wyboru u chorych na NDRP. Dotyczy to również chorych w I stopniu zaawansowania klinicznego, czyli z guzem $<3 \mathrm{~cm}$. Zgodnie z istniejącymi zaleceniami dotyczącymi leczenia chorych w I stopniu zaawansowania - ze względu na znacząco wyższą liczbę wznów miejscowych niż po wykonaniu lobektomii — resekcja klinowa i segmentektomia nie powinny być wykonywane. Podstawą do przyjęcia takiego dogmatu leczenia u chorych z wczesną postacią NDRP, u których nie ma przeciwwskazań medycznych do resekcji anatomicznej, jest prospektywne, randomizowane badanie kliniczne, które zakończyło się 26 lat temu, a zostało opublikowane w 1995 roku. Ginsberg i współpracownicy, na podstawie odległych wyników leczenia 264 chorych na NDRP w I stopniu zaawansowania, na drodze lobektomii lub resekcji o mniejszym zakresie niż lobektomia wykazali, że u tych ostatnich liczba nawrotów miejscowych jest 2,6 razy większa niż u pacjentów po lobektomii [1]. Dodatkowo wykazano, że spadek wydolności oddechowej mierzonej badaniami spirometrii nie różni się w zależności od tego, czy wykonano lobektomię czy resekcję mniejszą. Od tego czasu ukazało się wiele prospektywnych i retrospektywnych badań porównujących lobektomię z resekcją oszczędzającą, których skutki odległe dają sprzeczne wyniki dotyczące liczby nawrotów i całkowitego 5-letniego przeżycia w I stopniu zaawansowania NDRP [2-5]. Podstawą teoretyczną tłumaczącą wpływ zakresu resekcji na wyniki odległe są przerzuty do węzłów chłonnych wnęki pomimo klinicznej cechy NO oraz występowanie nowotworowej inwazji w naczyniach mikrokrążenia i naczyniach chłonnych wokół guza w 15-48\% przypadków NDRP w I stopniu zaawansowania $[6,7]$.

W wielu badaniach retrospektywnych autorzy sugerują jednak, że w guzach poniżej $2 \mathrm{~cm}$ średnicy segmentektomia daje odległe wyniki zbliżone do lobektomii, przy zachowaniu odpowiednio szerokiego $(>2 \mathrm{~cm}$ ) marginesu zdrowego miąższu płuca [2, 3]. Ze względu na brak randomizowanych kontrolowanych badań klinicznych na ten temat nie zaleca się jednak wykonywania resekcji mniejszej niż lobektomia, niezależnie od stopnia zaawansowania NDRP. Szansę na zmianę tej sytuacji dają dwa zakończone (JCOG0802, JCOG0804: Japonia) i jedno toczące się (CALGB140503, USA) randomizowane badania, porównujące segmentektomię z lobektomią w leczeniu NDRP $<2 \mathrm{~cm}$. Wyniki pierwszego z nich poznamy najwcześniej w 2018 roku, po zakończeniu 5-letniej obserwacji.

\section{Stereotaktyczna radioterapia (SBRT) - randomizowane badania}

Stereotaktyczna radioterapia jest stosunkowo niedawno wprowadzoną techniką napromieniania, która znalazła kliniczne zastosowanie u osób w I stopniu zaawansowania NDRP, ze względu na obciążenia ogólne niebędących kandydatami do leczenia chirurgicznego. Rozległe doświadczenia pozyskane w leczeniu tej grupy chorych, jak również obiecujące wyniki średnio odległe podawane przez autorów licznych retrospektywnych analiz zainicjowały dyskusję na temat zastosowania tej metody jako alternatywy dla chirurgicznego leczenia w I stopniu zaawansowania NDRP.

Katedra i Klinika Chirurgii Klatki Piersiowej

Gdański Uniwersytet Medyczny

Wystąpienie podczas II Konferencji Naukowej czasopisma Nowotwory „Debaty onkologiczne” 11-12 kwietnia 2014 roku 
Zaowocowało to w naturalny sposób rozpoczęciem trzech dużych randomizowanych badań klinicznych: Rosel, STARS, RTOG 1021, które mają za zadanie porównanie wyników leczenia wczesnego NDRP w drodze SBRT i chirurgii. Problemem okazała się rekrutacja do tych badań, a szczególnie do ramienia SBRT, co spowodowało zamknięcie dwóch z nich: holenderskiego Rosel i amerykańskiego RTOG 1021. W okresie 3 lat naboru do trzech wyżej wymienionych programów zakwalifikowano 2410 osób, z czego jedynie 68 do ramienia SBRT. Brak randomizowanych badań porównujących wyniki leczenia SBRT z leczeniem chirurgicznym u chorych na NDRP w I stopniu zaawansowania nie pozwala na ocenę stereotaktycznej radioterapii jako alternatywnej do chirurgii metody leczenia, co wyklucza jej zastosowanie u chorych kwalifikujących się do leczenia chirurgicznego.

\section{SBRT — retrospektywne i prospektywne badania}

SBRT jest na pewno metodą, która daje stosunkowo małą liczbę powikłań. Odsetek wczesnych zgonów jest także niski i nie przekracza zwykle 1\% we wczesnym: 30-dniowym okresie po napromienianiu. Haaselbeck i wsp., Sadhu i wsp. oraz Takeda i wsp. opublikowali retrospektywne analizy leczenia chorych powyżej 80 roku życia. Powikłania III i IV stopnia wystąpiły w tych trzech opracowaniach odpowiednio u 3,6\%, 0\% i 2\%, a zgony u odpowiednio u 0\%, 0\% i 0,9\%. Badania te pokazują, że leczenie tą metodą jest bezpieczne, szczególnie w okresie wczesnym.

Szereg wątpliwości nasuwa w kontekście powikłań kolejna ważna publikacja, a raczej szeroko cytowane przez radioterapeutów dane. Shirvani i wsp. na podstawie amerykańskiej epidemiologicznej bazy danych SEER opublikowali wyniki leczenia NDRP w I stopniu zaawansowania w drodze lobektomii, segmentektomii, SBRT, konwencjonalnej radioterapii lub jedynie obserwacji [8]. Cytowania dotyczą najczęściej 90-dniowej, okołointerwencyjnej śmiertelności, wskazując, że śmiertelność po lobektomii, segmentektomii i SBRT wynosi po tym okresie odpowiednio 4,1\%, 5,6\% i 0,8\%. Publikacja ta, jak również cytowane dane wymagają komentarza. Dane te dotyczą jedynie USA i są niepównywalne z wynikami europejskimi. Jest to spowodowane tym, że operacje u chorych na raka płuca są wykonywane w Stanach Zjednoczonych głównie przez chirurgów ogólnych, którzy wykonują kilka lub kilkanaście podobnych zabiegów rocznie. Według tego samego źródła limfadenektomia nie jest tam wykonywana u 62\% operowanych chorych. SBRT wykonywana jest z kolei w najlepszych ośrodkach radioterapii w USA. Jest to więc klasyczne porównanie jabłek z gruszkami.

W znakomitej większości retrospektywnych i prospektywnych badań dotyczących SBRT głównym celem jest ocena miejscowej kontroli. Istnieje bardzo duża zbieżność wyników dotyczących 2-3-letniego przeżycia i kontroli miej- scowej w obu typach badań. Autorzy najważniejszych prospektywnych analiz wykazali w łącznej grupie 328 (40-70) nieoperacyjnych chorych, że przeżycie wynosiło średnio $52,1 \%$ (43-75\%), a kontrola miejscowa średnio 91,2\% (84-98\%) w okresie 2-3 lat od napromieniania [9-14], podczas gdy w największych trzech retrospektywnych badaniach wśród łącznie 2049 (514-859) chorych całkowite przeżycie i kontrola miejscowa wynosiły odpowiednio 51,3\% (46-62\%) oraz 91\% (80-95\%) po takim samym okresie [15-17]. Są trzy aspekty, na które warto zwrócić uwagę w kontekście wymienionych prac: po pierwsze wyniki — retrospektywnych i prospektywnych analiz są zbieżne, czyli powtarzalne, po drugie - należy pamiętać, że wyniki te dotyczą populacji bardzo obciążonej, co korzystnie świadczy o skuteczności i bezpieczeństwie SBRT, jednakże okres obserwacji jest zdecydowanie za krótki na wyciągnięcie definitywnych wniosków z przytoczonych wyników.

\section{SBRT - metaanalizy}

W ostatnich latach ukazało się szereg mataanaliz porównujących wyniki leczenia wczesnego raka płuca przy zastosowaniu SBRT z leczeniem standardowym w tym schorzeniu, jakim jest leczenie chirurgiczne [18-23]. Do analizy statystycznej w metaanalizach porównujących SBRT z chirurgią w I stopniu zaawansowania klinicznego używana jest powszechnie metoda Propensity Score Matched Analysis (PSMA), będąca jedną ze strategii korygujących, która koryguje zaburzenia naboru (selection bias) w przeprowadzeniu analizy statystycznej. Jest to wiarygodna metoda pod warunkiem spełnienia szeregu wymogów. Przede wszystkim potrzeba dużych zbiorów danych w obu analizowanych grupach. Ograniczenia są dość istotne w przypadku niewłaściwego wytypowania czynników doboru lub np. porównywania małej grupy z dużą grupą, lub/i porównywania grup bez istotnego podobieństwa. Wczesnych zaburzeń (2-3 lata) jest przy tym istotnie mniej niż średnioterminowych (3-5 lat), co powoduje, że w okresie wczesnym wartość porównawcza grup znacząco spada. Wiele zależy zatem od intencji autora, który decyduje się na taką analizę. Jeśli nie zastosuje się do tych wymogów, wyniki mogą być zafałszowane. PSMA, choć interesująca, nie może zastąpić randomizowanych badań.

W dostępnych metaanalizach dotyczących leczenia wczesnego raka płuca przy zastosowaniu SBRT zwraca uwagę przede wszystkim duża dysproporcja w liczebności grup pomiędzy analizowanymi metodami leczenia, czyli SBRT i chirurgią, a podobieństwa porównywanych grup w związku z tym są niedostateczne. Również okres obserwacji dla SBRT jest zazwyczaj krótki, 2-3-letni. Poprzez wymienione ograniczenia wartość opublikowanych metaanaliz jest dyskusyjna. Wyniki większości z tych analiz wykazują brak istotnych różnic w całkowitych przeżyciach i przeżyciach zależnych od nowotworu dla SBRT i chirurgii, lecz dotyczy to głównie wczesnych wyników [18-23]. 
Przykładem są opublikowane przez Verstegena i wsp. porównania kontroli miejscowej u 527 chorych leczonych w drodze SBRT i 86 lobektomii VATS, wykonanych w 6 szpitalach [18]. Dane dotyczące SBRT pochodziły z jednej instytucji. Chorych dobrano, uwzględniając w analizie PSM: TNM, wiek, płeć, funkcję płuca, Charlson comorbidity score i stan sprawności. Nie stwierdzono różnic dotyczących całkowitego przeżycia i lepszej kontroli miejscowej w grupie radioterapii. Obserwacja trwała dla SBRT i VATS odpowiednio 30 i 16 miesięcy.

Onishi i wsp. przeanalizowali retrospektywnie wieloośrodkową bazę danych dotyczącą leczenia operacyjnych chorych w drodze SBRT [23]. W tracie trwania obserwacji (średnio 55 miesięcy) kontrola miejscowa dla guzów T1 iT2 wynosiła po 5 latach odpowiednio 92\% i 73\%. Całkowite 5-letnie przeżycia w stopniu IA i IB wyniosły odpowiednio $72 \%$ i $62 \%$. Dane te zostały porównane wynikami IASLC dotyczącymi leczenia chirurgicznego ponad 100000 chorych na NDRP zebranych w bazie danych pochodzącej z kilkuset instytucji na świecie, wykazując porównywalne wyniki dotyczące całkowitego 5-letniego przeżycia w obu metodach leczenia.

Cytowani już powyżej Shirvani i wsp. dokonują metaanalizy, porównując leczenie wczesnego raka płuca w drodze SBRT, lobektomii i resekcji mniejszej niż lobektomia (resekcja klinowa) przy zastosowaniu PSMA w odniesieniu do wczesnych i,późniejszych"wyników [8]. Zestawienie dotyczy 7008 chorych leczonych chirurgicznie i 124 leczonych SBRT. Średni okres obserwacji wynosił 3,2 roku. SBRT charakteryzowało się najniższym ryzykiem zgonu w okresie do 6 miesięcy od rozpoznania (współczynnik ryzyka [HR] 0,48; 95\% przedział ufności [CI] 0,38-0,63). Po upływie 6 miesięcy w grupie lobektomii obserwowano najwyższy odsetek całkowitego przeżycia i przeżycia związanego z nowotworem przy zastosowaniu regresyjnego modelu Coxa. Po dwóch latach śmiertelność była najniższa po lobektomii (18,3\%), następnie po segmentektomii $(25,1 \%)$, i wreszcie po SBRT $(41,1 \%)$. Po zastosowaniu analizy PSM przeżycia nie różniły się w grupie SBRT i lobektomii.

\section{SBRT versus termoablacja (RFA — radiofrequency ablation)}

W rozważaniach na temat zastosowania nowoczesnych małoinwazyjnych metod leczenia raka płuca w I stopniu zaawansowania nie sposób pominąć alternatywnej metody dla SBRT, czyli termoablacji. Jest to metoda miejscowego zniszczenia guza za pomocą ciepła wytworzonego przez przepływający przez tkanki prąd zmienny o wysokiej częstotliwości (300-500 kHz). Jest to najtańsza procedura ze wszystkich omawianych w niniejszym artykule. Szerokie zastosowanie RFA w leczeniu miejscowym guzów wątroby nie przełożyło się na jej zastosowanie w raku płuca. W 2013 roku Tramontano i wsp. opublikowali modelingo- we badania oparte na prospektywnych badaniach II fazy SBRT i prospektywnym badaniu RFA „RUPTURE”, dotyczących leczenia nieoperacyjnych chorych na NDRP w I stopniu zaawansowania i służących określeniu przewidywanej przydatności tych potencjalnie atrakcyjnych alternatywnych metod leczenia miejscowego NDRP [24]. Symulacja została wykonana w oparciu o kalibrację, która uwzględniała dane z rejestru guzów, badań obserwacyjnych oraz prospektywnych badań RFA i SBRT.

W każdej z metod przyjęto symulację, dotyczącą ok. 2000 pacjentów z NDRP w I stopniu zaawansowania. Wyniki symulacji SBRT i RFA odniesiono do wyników tradycyjnej radioterapii, wykazując przedłużenie przeżycia wynoszące 1,46 roku dla chorych leczonych SBRT i 1,71 roku leczonych RFA w porównaniu z chorymi leczonymi klasyczną radioterapią.

Wyniki dotyczące powikłań, śmiertelności i zachorowalności okołointerwencyjnej w grupie SBRT i RFA były prawie identyczne.

Wskazuje to na potrzebę zaprojektowania badania randomizowanego z udziałem trzech sposobów leczenia: chirurgii, SBRT i RFA w przypadku planowania porównawczej analizy skuteczności oszczędzających metod leczenia miejscowego w I stopniu zaawansowania NDRP.

\section{Wnioski i uwagi}

W onkologii najważniejszym celem wszelkich badań jest ocena całkowitego przeżycia lub przeżycia wolnego od nawrotu z dokładnym określeniem miejsca nawrotu. Przerzuty regionalne lub odległe mogą wystąpić w każdym momencie obserwacji bez cech wznowy miejscowej, zatem ocena kontroli miejscowej jest niewystarczająca. Dodatkowo okres obserwacji powinien wynosić co najmniej 5 lat, a we wczesnych stopniach zaawansowania prawdopodobnie znacznie dłużej. Dostępne badania dotyczące leczenia NDRP w I stopniu zaawansowania przy zastosowaniu SBRT nie spełniają w znakomitej większości tych kryteriów. Odpowiedź na pytanie, czy SBRT może być alternatywą dla leczenia chirurgicznego w tym stadium choroby u chorych bez przeciwwskazań do lobektomii, uzyskać można jedynie na drodze randomizowanego badania.

Na podstawie dotychczasowych badań dotyczących zakresu resekcji wydaje się, że lobektomia nadal pozostanie standardem leczenia raka płuca w I stopniu zaawansowania. Istnieją przesłanki kliniczne sugerujące, że segmentektomia z marginesem co najmniej $2 \mathrm{~cm}$ od guza może być alternatywą dla lobektomii jedynie w guzach poniżej $2 \mathrm{~cm}$ średnicy. Wymaga to również potwierdzenia w badaniach randomizowanych, do zakończenia których droga wydaje się być obecnie krótsza niż do badania porównującego "chirurgię radiacyjną" z chirurgią manualną (z grec. cheirurgia - ręcznie wykonywana praca). Trudno zatem przypuszczać, że leczenie oszczędzające (wycięcie klinowe lub 
SBRT) w najbliższym okresie znajdzie szerokie zastosowanie $w$ rutynowym leczeniu I stadium raka płuca, skoro większość badań z wieloletnią obserwacją porównujących segmentektomię anatomiczną (szerszy zakres niż wycięcie klinowe) z wycięciem klinowym wykazuje dużo gorsze wyniki odległe tej ostatniej.

W publikacjach na temat zastosowania SBRT u operacyjnych chorych jest szereg kwestii, które budzą wątpliwości z onkologicznego punktu widzenia. Najistotniejszą, o której już wspomniałem, jest to pewnego rodzaju „,manipulacja danymi" poprzez zastosowanie nowoczesnych statystycznych technik, nie biorąc pod uwagę ograniczeń i wymogów, które powinny być uwzględnione, aby analiza była wartościowa. Obserwacja 5-letnia powinna być zakończona, aby można było w ogóle dyskutować na temat skuteczności jakiejkolwiek interwencji w onkologii. Być może w I stopniu NDRP 10-letnia obserwacja daje bardziej wiarygodne dane.

Kolejnym ograniczeniem zastosowania radioterapii we wczesnym raku płuca jest ograniczenie możliwości leczenia uzupełniającego u chorych, którzy tego leczenia wymagają, poprzez brak możliwości dokładnej oceny histopatologicznej charakteru guza (np. rak mieszany) oraz brak oceny regionalnych węzłów chłonnych. Poprzez ablację guza zaprzepaszcza się szansę na uzyskanie materiału do badań molekularnych w celu zastosowania leczenia celowanego, jak i prowadzenia badań naukowych. Ma to szczególne znaczenie, ponieważ u 10\% chorych we wczesnym stadium w okresie 10 lat rozwinie się drugi pierwotny nowotwór płuca, a następne $20 \%$ będzie miało nawrót choroby. W tym kontekście szczególnie bulwersujący jest fakt leczenia znacznego odsetka chorych bez rozpoznania histopatologicznego, a jedynie na podstawie badania PET.

Proponuję na zakończenie porzucić mylące pojęcie „radiochirurgii” ze względów semantycznych, jak również merytorycznych - nie mamy, jak do tej pory, dowodów, że SBRT może być alternatywą dla chirurgicznego leczenia raka płuca w I stopniu zaawansowania. Leczenie to może być stosowane u chorych, którzy nie są kandydatami do wykonania lobektomii ze względu na ograniczone rezerwy oddechowe lub zły stan ogólny. Istnieje potrzeba przeprowadzenia randomizowanych badań porównujących odległe wyniki leczenia metodami chirurgicznymi, stereotaktyczną radioterapią, jak również innymi metodami leczenia miejscowego, np. termoablacją. Wybór małoinwazyjnej, optymalnej metody pod względem odległego przeżycia bez nawrotu choroby oraz dającej najmniejszy odsetek powikłań w leczeniu chorych na wczesnego raka płuca jest ważnym zadaniem współczesnej onkologii.

\section{Prof. dr hab. n. med. Witold Rzyman}

Katedra i Klinika Chirurgii Klatki Piersiowej

Gdański Uniwersytet Medyczny

e-mail:wrzyman@gumed.edu.pl

\section{Piśmienictwo}

1. Ginsberg RJ, Rubinstein LV. Randomized trial of lobectomy versus limited resection for T1 N0 non-small cell lung cancer. Lung Cancer Study Group. Ann Thorac Surg 1995; 60: 615-623.

2. Okada M, Koike T, Higashiyama M i wsp. Radical sublobar resection for small — sized non-small cell lung cancer: a multicenter study. J Thorac Cardiovasc Surg 2006; 132: 769-775.

3. Schuchert MJ, Pettiford BL, Keeley S i wsp. Anatomic segmentectomy in the treatment of stage I non-small cell lung cancer. Ann Thorac Surg 2007; 84: 926-933.

4. Whitson BA, Groth SS, Andrade RS i wsp. Survival after lobectomy versus segmentectomy for stage I non-small cell lung cancer: a population-based analysis. Ann Thorac Surg 2011; 92: 1943-1950.

5. Bao F, Ye P, Yang Y i wsp. Segmentectomy or lobectomy for early stage lung cancer: a meta-analysis. Eur J Cardiothorac Surg 2014; 46: 1-7.

6. Tao H, Hayashi T, Sano F i wsp. Prognostic impact of lymphovascular invasion compared with that of visceral pleural invasion in patients with pN0 non-small-cell lung cancer and a tumor diameter of $2 \mathrm{~cm}$ or smaller. J Surg Res 2013; 185: 250-254.

7. Miyoshi K, Moriyama S, Kunitomo T i wsp. Prognostic impact of intratumoral vessel invasion in completely resected pathologic stage I non-small cell lung cancer. J Thorac Cardiovasc Surg 2009; 137: 429-434.

8. Shirvani SM, Jiang J, Chang JY i wsp. Comparative effectiveness of five treatment strategies for early-stage non-small cell lung cancer in the elderly. Int J Radiat Oncol Biol Phys 2012; 84: 1060-1070.

9. Timmerman R, Paulus R, Galvin Ji wsp. Stereotactic body radiation therapy for inoperable early stage lung cancer. JAMA 2010; 303: 1070-106.

10. Bral S, Gevaert T, Linthout N i wsp. Prospective, risk-adapted strategy of stereotactic body radiotherapy for early-stage non-small-cell lung cancer: results of a Phase II trial. Int J Radiat Oncol Biol Phys 2011; 80: 1343-1349.

11. Nagata Y, Takayama K, Matsuo Y i wsp. Clinical outcomes of a phase I/II study of $48 \mathrm{~Gy}$ of stereotactic body radiotherapy in 4 fractions for primary lung cancer using a stereotactic body frame. Int J Radiat Oncol Biol Phys 2005; 63: 1427-1431.

12. Fakiris AJ, McGarry RC, Yiannoutsos CT i wsp. Stereotactic body radiation therapy for early-stage non-small-cell lung carcinoma: four-year results of a prospective phase II study. Int J Radiat Oncol Biol Phys 2009; 75: 677-682.

13. Baumann P, Nyman J, Hoyer Mi wsp. Stereotactic body radiotherapy for medically inoperable patients with stage I non-small cell lung cancer - a first report of toxicity related to COPD/CVD in a non-randomized prospective phase II study. Radiother Oncol 2008; 88: 359-367.

14. Ricardi U, Filippi AR, Guarneri A i wsp. Stereotactic body radiation therapy for early stage non-small cell lung cancer: results of a prospective trial. Lung Cancer 2010; 68: 72-77.

15. Senthi S, Lagerwaard FJ, Haasbeek CJ i wsp. Patterns of disease recurrence after stereotactic ablative radiotherapy for early stage non-small-cell lung cancer: a retrospective analysis. Lancet Oncol 2012; 13: 802-809.

16. Guckenberger $M$, Allgäuer $M$, Appold S i wsp. Safety and efficacy of stereotactic body radiotherapy for stage 1 non-small-cell lung cancer in routine clinical practice: a patterns-of-care and outcome analysis. J Thorac Oncol 2013; 8: 1050-1058.

17. Grills IS, Hope AJ, Guckenberger M i wsp. A collaborative analysis of stereotactic lung radiotherapy outcomes for early-stage non-small-cell lung cancer using daily online cone-beam computed tomography image-guided radiotherapy. J Thorac Oncol. 2012; 7: 1382-1393.

18. Verstegen NE, Oosterhuis JW, Palma DA i wsp. Stage I-II non-small-cell lung cancer treated using either stereotactic ablative radiotherapy (SABR) or lobectomy by video-assisted thoracoscopic surgery (VATS): outcomes of a propensity score-matched analysis. Ann Oncol 2013; 24: $1543-1548$.

19. Varlotto J, Fakiris A, Flickinger J i wsp. Matched-pair and propensity score comparisons of outcomes of patients with clinical stage I nonsmall cell lung cancer treated with resection or stereotactic radiosurgery. Cancer 2013; 119: 2683-2691.

20. Puri V, Crabtree TD, Kymes S i wsp. A comparison of surgical intervention and stereotactic body radiation therapy for stage I lung cancer in high-risk patients: a decision analysis. J Thorac Cardiovasc Surg 2012; 143: 428-436.

21. Grills IS, Mangona VS, Welsh R i wsp. Outcomes after stereotactic lung radiotherapy or wedge resection for stage I non-small-cell lung cancer. J Clin Oncol 2010; 28: 928-935.

22. Soldà $F$, Lodge $M$, Ashley $\mathrm{S}$ i wsp. Stereotactic radiotherapy (SABR) for the treatment of primary non-small cell lung cancer; systematic review and comparison with a surgical cohort. Radiother Oncol 2013; 109: 1-7.

23. Onishi $\mathrm{H}$, Shirato $\mathrm{H}$, Nagata $\mathrm{Y}$ i wsp. Stereotactic body radiotherapy (SBRT) for operable stage I non-small-cell lung cancer: can SBRT be comparable to surgery? Int J Radiat Oncol Biol Phys 2011;81: 1352-1358.

24. Tramontano AC, Cipriano LE, Kong CY i wsp. Microsimulation model predicts survival benefit of radiofrequency ablation and stereotactic body radiotherapy versus radiotherapy for treating inoperable stage i non-small cell lung cancer. AJR 2013; 200: 1020-1027. 